DOI 10.4467/2543733XSSB.21.012.13805

\author{
LILLA MOROZ-GRZELAK
}

Instytut Slawistyki PAN

\title{
SFERA SYMBOLICZNA W PROCESACH TRANSFORMACYJNYCH KRAJÓW BYLEJ JUGOSŁAWII. POMNIKI
}

\author{
The Symbolic Sphere in the Transformation Processes of the former Yugoslavia. Monuments
}

\author{
Summary
}

The article focuses on the ways of treating the monumental memory of the past in the states that were established after the disintegration of Yugoslavia. These examples, which are not exhaustive, show that the process of transformation in the symbolic sphere does not create a uniform image in all countries. It oscillates between the destruction of the monuments of the past period in Slovenia, Croatia and Bosnia and Herzegovina, but also the different intensity of the events of the tragic war of the last decade of the 20th century. Breaking such a description, Serbia protects the monuments of the Yugoslavian era, while at the same time recalling the memory of the Serbian liberation struggle in the anti-Turkish uprising of 1804. The protection of the monuments of the NOB (struggle for national liberation) period in Montenegro not only proves the connection with the federal Yugoslavia, but also reflects a kind of Yugonostalgia. In turn, the monuments of this period on Macedonian territory, preserved in various states, gave way to a "flood of monuments" referring to the ancient and medieval history of this land. The changes in the monumental sphere in all countries, however, prove the willingness to justify the ideological existence of independent state entities embedded in the native tradition confirming their sovereignty.

Key words: monuments to the struggle for national liberation, transformation of post-Yugoslavian countries, symbolic sphere

Słowa kluczowe: pomniki walki narodowowyzwoleńczej, transformacja krajów pojugosłowiańskich, sfera symboliczna

Celem artykułu jest ukazanie przemian zachodzących w sferze symbolicznej w krajach powstałych po rozpadzie Jugosławii ${ }^{1}$. W wyniku tego rozpadu po raz pierwszy status nie-

${ }^{1}$ Nie podejmuję się tu polemiki ze zróżnicowanymi stanowiskami terminologicznymi o rozpadzie, rozbiciu czy upadku Jugosławii. Zob.: M. Waldenberg, Rozbicie Jugosławii: jugosłowiańskie lustro międzynarodowej 
zależnych państw zyskały Słowenia i Macedonia, przywrócona została niezawisłość państwowa Chorwacji i Serbii, Czarnogóra ogłosiła samodzielność, Bośnia i Hercegowina krwawo wywalczyła niezależność, stając się państwem kantonalnym łączącym zróżnicowane etnosy, a na ziemiach historycznie serbskich proklamowano Republikę Kosowo.

Odnosząc się do procesów transformacyjnych, jakie zachodziły w sferze symbolicznej w nowych organizmach politycznych, które wyłoniły się z federacyjnej Jugosławii, pominę tu kwestię zmian, jakie nastąpiły w oficjalnej symbolice państwowej, kiedy każdy z nowych krajów odrzucił obowiązujące w okresie jugosłowiańskim flagi i godła, przyjmując zupełnie nowe lub wprowadzając takie, które odwoływały się do swoich historycznych tradycji ${ }^{2}$. Pominę też zagadnienia onomastycznych zmian miejscowości oraz ulic, jakie przeprowadzano w poszczególnych krajach, demonstrując w ten sposób zerwanie z dziedzictwem wielonarodowego państwa i zastępując takimi, które przez odwołania do swej przeszłości miały potwierdzać własną niezależność. Proces transformacji - obejmujący rozliczenia z okresem minionym - zostanie tu ukazany na bazie materiałowej czerpanej w dużej mierze ze źródeł internetowych, a odnoszącej się do losów pomników, jakie stawiano w federacyjnej Jugosławii po zakończeniu II wojny światowej. W okresie trwania Jugosławii, poprzez konsekwentnie prowadzoną politykę, miały one uzasadniać jej istnienie - podstawę ideową stanowiła pamięć o partyzanckiej walce narodowowyzwoleńczej - NOB (Narodnooslobodilačka borba) pod wodzą Josipa Broza Tity z hasłem „braterstwa i jedności" (bratstvo i jedinstvo) wszystkich wchodzących w jego skład etnosów. Artykuł stanowi próbę odpowiedzi na pytania: czy były one niszczone, jeśli tak, to w jakich okolicznościach, czym je zastępowano, i czy we wszystkich nowych krajach pojugosłowiańskich był to proces zbliżony i służący tym samym celom.

Kwestia upamiętniania pewnych wydarzeń i postaci w pomnikach, tablicach czy obeliskach - i ich ewentualne zastępowanie innymi, nie jest zjawiskiem nowym. W obszernym opisie funkcji i znaczenia pomników, zamieszczonym w Encyklopedii staropolskiej ilustrowanej Zygmunta Glogera, której kolejne tomy wydawano w latach 1900-1903, pod hasłem „pomniki” czytamy, że to „monument dla pamięci lub na pamiątkę wystawiony, pamiątka czego zachowana, wiekopomna"3. Wskazuje się przy tym na uzależnione od okoliczności i czasów stawianie w ich miejscu pomników o zupełnie innym charakterze i wymowie. Potwierdza to współcześnie Aleida Assmann, zwracając uwagę na instrumentalne wykorzystywanie pomników, które poza wystawami, rekonstrukcjami historycznymi i filmem stanowią jedno z narzędzi polityki historycznej państw ${ }^{4}$.

Pomniki doby jugosłowiańskiej już na początku rozpadu federacji, jako symbole popełnionych w przeszłości zbrodni, w niektórych nowych państwach były często niszczone w pierwszej kolejności. Stanowiło to swoistą próbę wymazywania z pamięci społeczeństw pewnych postaci i wydarzeń, które zastępowano zupełnie nowymi lub przywracano w ich

polityki, t. 1-2, Warszawa 2005; M. Zacharias, Komunizm, federacja, nacjonalizmy. System władzy w Jugosławii 1943-1991. Powstanie, przeksztatcenia, rozkład, Warszawa 2004.

${ }^{2}$ L. Moroz-Grzelak, Emblematyczne formy manifestowania wartości w świecie postjugosłowiańskim. Patriotyzm, [w:] Konstrukcje i destrukcje tożsamości. Wartości w świecie słowiańskim, red. E. Golachowska, D. Pazio-Wlazłowska, Warszawa 2015, s. 355-368.

${ }^{3}$ H. Łopaciński, Pomniki, [w:] Z. Gloger, Encyklopedia staropolska ilustrowana, reprint, wstęp J. Krzyżanowski, t. 4, Warszawa 1978, s. 72-94.

${ }^{4}$ A. Assmann, Między pamięcia a historią. Antologia, red. M. Saryusz-Wolska, Warszawa 2013. 
miejsce te kultywowane przed wybuchem II wojny światowej. Stawiane w okresie Jugosławii pomniki, często $\mathrm{z}$ dobrymi intencjami upamiętnienia poległych na danym terytorium, w nowych czasach okazały się w wielu przypadkach nieodpowiednie. Takie zjawisko zaobserwował Božidar Jezernik, krytycznie odnoszący się do usuwania tych pochodzących z minionej epoki w słoweńskiej przestrzeni, zauważając, że „Słoweńcy są dumni, że nie są częścią Bałkanów, a mimo to ich najbardziej »bałkańską" cechą pozostaje erozja pozostałości z przeszłości" ${ }^{\text {. }}$. Etnolog nie wyrażał w ten sposób zgody na pozbawianie Słowenii śladów jej wcześniejszej historii.

Słowenia 25 czerwca 1991, wraz z Chorwacją, odłączyła się od Jugosławii, co dwa dni później zapoczątkowało w tym kraju wojnę dziesięciodniową (desetdnevna vojna), która trwała od 27 czerwca do 7 lipca 1991. Po ukonstytuowaniu się nowego państwa niszczono wiele pomników nawiązujących do przeszłości państwa federacyjnego i relacji sowiecko-słoweńskich. W lokalnym wymiarze jednak wiele z nich się zachowało. Były to najczęściej obeliski, tablice pamiątkowe czy pomniki bohaterów walk za dany region, często zlokalizowane przy kościołach, z wypisanymi nazwiskami ofiar II wojny światowej. Jak zauważa słoweńska historyk sztuki, Beti Žerovc, większość upamiętnień wznoszonych po I i II wojnie światowej w Słowenii nie miała charakteru ideologicznego, ale pojawiała się dla uhonorowania tych, którzy zginęli w walkach. Stawiane były często z inicjatywy lokalnych stowarzyszeń kombatantów, a instytucje państwowe w mniejszym stopniu, niż się to wydaje, były włączone w stawianie pomników $\mathrm{NOB}^{6}$.

Galerię pomników odsłoniętych po II wojnie światowej otwiera „Pomnik Zwycięstwa” z sierpnia 1945 roku w miejscowości Murska Sobota ${ }^{7}$. Ten monument zachował się tylko dzięki determinacji i decyzji miejscowych władz, które skutecznie przekonały społeczeństwo, że pozostaje on świadectwem walk, jakie toczyły się w Prekmuriju, i dowodzi dzielności Słoweńców tego regionu. Jednak część zachowanych w przestrzeni miejskiej Słowenii pomników, poświęconych bitwom II wojny, zdemontowano, a wiele z zachowanych do tej pory często nadal podlega aktom wandalizmu. Przykładem jest „Pomnik Rewolucji”, odsłonięty w 1975 roku$^{8}$, a zlokalizowany na Placu Republiki w Lublanie. Ten monument, podobnie jak i postawiony w 1960 roku posag Borisa Kidriča (1912-1953), jugosłowiańskiego i słoweńskiego polityka, dowódcy ruchu rewolucyjnego, uczestnika walk narodowowyzwoleńczych i państwowego bohatera Jugosławii w randze generała-podpułkownika Jugosłowiańskiej Armii Ludowej (JNA), sukcesywnie oblewany jest czerwoną farbą ${ }^{9}$. Akty wandalizmu uzasadniane są brakiem zgody na przypominanie w przestrzeni miasta mrocznej karty historii Słowenii z okresu, kiedy stanowiła jedną z jugosłowiańskich republik ${ }^{10}$.

${ }^{5}$ Tak mówił B. Jezernik przy okazji promocji swojej książki poświęconej miejscom pamięci Mesto brez spomina. Javni spomeniki v Ljubljani z 2015 roku. Zob.: T. Lešničar, Kako in komu postavljamo spomenike, „Delo” 2017, https://www.delo.si/sobotna/kako-in-komu-postavljamo-spomenike.html, (dostęp: 10.09.2019).

${ }^{6}$ Ibidem.

${ }^{7}$ Spomenik zmage zaprojektował architekt z Armii Sowieckiej Vladimir Arončik. Autorami rzeźb żołnierzy byli słoweńscy twórcy Boris i Zdenko Kalina. Informacje o twórcach oraz zdjęcia poszczególnych pomników w Słowenii pochodzą ze strony internetowej Simboli polpretekle zgodovine. Zob.: http://spomeniki.blogspot. com/search/label/AVNOJ, (dostęp: 9.09.2019).

${ }^{8}$ Autorami symbolicznego pomnika z brązu o wysokości $11 \mathrm{~m}$ są Drago Tršar i Vladimir Braco Mušič.

${ }^{9}$ Autorem posagu jest Zdenko Kalina.

${ }^{10}$ VLjubljani oskrunili več spomenikov, https://www.rtvslo.si/crna-kronika/v-ljubljani-oskrunili-vec-spomenikov/493550; z 3.07.2019, (dostęp: 29.09.2019). 
Próbę uporządkowania kwestii słoweńskiej historii, która poprzez stawiane monumenty miałaby połączyć wszystkich mieszkańców kraju, podjęły władze słoweńskie, odsłaniając uroczyście, z udziałem Gwardii Honorowej i prezydenta Boruta Pahora, 13 lipca 2017 roku „Pomnik Ofiar Wszystkich Wojen”, poświęcony wszystkim dotkniętym w jakikolwiek sposób przez wojny. Przyjęta koncepcja ma pozwolić na pielęgnowanie pamięci ofiar I i II wojny światowej, bojowników o północną granicę Słowenii i walk o wyzwolenie narodowe, poszkodowanych w wyniku przemocy rewolucyjnej i antyrewolucyjnej, powojennych poległych, którzy stracili życie w wyniku pozasądowych zabójstw i oskarżeń karnych oraz zabitych w wojnie o niepodległość. Władze miejskie i państwowe uznały ten pomnik za najważniejsze upamiętnienie w trwającym procesie pojednania narodu słoweńskiego. Na pomniku znalazł się cytat pochodzący z rękopisu z 1949 roku słoweńskiego poety i pisarza Otona Župančiča (1878-1949): „Ojczyzna jest jedna, dana nam wszystkim / i jedno życie i jedna śmierć!" (Domovina je ena / nam vsem dodeljena, / in eno življenje, / in ena smrt). W założeniu twórców ten właśnie pomnik to zachęta do życia w harmonii, w zrozumieniu, przebaczeniu, współpracy, pokoju i pojednaniu. Jednak krytycy monumentu, wyrażając swój sprzeciw wobec jego istnienia, dla wzmocnienia swej niechęci do takiej pomnikowej komemoracji podają jego koszty, zbliżone do kwoty 1,2 miliona euro ${ }^{11}$.

Wymiar ogólnopaństwowy pogodzenia pamięci o przeszłości w zachowanych i nowo odsłanianych pomnikach styka się z wymiarem lokalnym i prywatnym w kultywowaniu pamięci o zasłużonych dla państwa słoweńskiego postaciach. Taką funkcję pełnić ma pomnik-ławeczka Edvarda Kocbeka (1904-1981), polityka, pisarza, publicysty, zaliczanego do najważniejszych intelektualistów i wielkich autorytetów moralnych Słowenii XX wieku, który w 2005 roku w parku Tivoli w Lublanie zyskał upamiętnienie w postaci ławeczki zaprojektowanej przez jego wnuka, Pavela Kocbeka ${ }^{12}$. Śladów odniesień do wojny 10-dniowej z armią jugosłowiańską jest w przestrzeni słoweńskiej niewiele w porównaniu z Chorwacją. Takim przykładem jest odsłonięty w 1996 roku we wsi Prilipe nad rzeką Sawą, niedaleko granicy z Chorwacją, betonowy blok zapory przeciwczołgowej, upamiętniający zatrzymanie 2 lipca 1991 roku przez oddział szturmowy Obrony Terytorialnej Brežice oddziału pancernego armii jugosłowiańskiej.

Kwestia pamięci o przeszłości odzwierciedlanej w pomnikach nieco inaczej wygląda w Chorwacji. Jak zauważa Ewa Szperlik, dokonując analizy chorwackiej prozy biograficznej i literatury fikcjonalnej poruszającej tematy przez dziesięciolecia istnienia federacyjnego państwa przemilczane; Jugosławia jest w niej postrzegana jako opresyjne imperium i więzienie narodów, w którym etnos chorwacki był szczególnie represjonowany ${ }^{13}$. Odzwierciedlenie takiego stanowiska widoczne jest także w stosunku do pomnikowych upamiętnień. Szacuje się, że w latach 1945-1990 na terenie Chorwacji odsłonięto około 6 tysięcy pomników, popiersi i tablic pamiątkowych poświęconych wydarzeniom i postaciom ruchu narodowowyzwoleńczego Chorwacji i Jugosławii. Jak wskazują dane, dokład-

\footnotetext{
${ }^{11}$ Zespołowy projekt pomnika Žrtvam vseh vojn wyłoniono w zorganizowanym konkursie. Zob.: P. Hribar, Ne spomenik vsem žrtvam vojn, pač pa Slovencu vojaku, „Casovnik”. https://www.casnik.si/spomenik-posvecenvsem-zrtvam-vojn/. M. Lisjak, Če je to vredno 1,2 milijona, je 2. tir še zelo poceni, https://www.rtvslo.si/mmcdebata/mmcdebata-ce-je-to-vredno-1-2-milijona-je-2-tir-se-zelo-poceni/427744, (dostęp: 29.09.2019).

${ }^{12}$ Zob.: http://spomeniki.blogspot.com/search/label/AVNOJ (dostęp: 9.09.2019).

${ }^{13}$ E. Szperlik, Chorwacka (nie)pamięć o Jugosławii. Przemilczenia, pominięcia i odpamiętanie w prozie chorwackiej po roku 1991, Poznań 2019, s. 261.
} 
nie 2964 z nich (731 pomników i 2233 tablice) zostały zniszczone lub uszkodzone w okresie od roku 1990 do 2000. Jednak współcześnie część z nich podlega aktom wandalizmu i podobnie jak w Słowenii jest niszczona za pomocą czerwonej farby. Dla redaktora opublikowanego spisu pomników z tego okresu, byłego partyzanta, Juraja Hrženjaka, ocalenie i renowacja pozostałych pomnikowych upamiętnień walk antyfaszystowskich leży w interesie zachowania prawdy historycznej o minionych czasach ${ }^{14}$.

Akty wandalizmu ${ }^{15}$ śledzi istniejące w Chorwacji pismo „Antifašistički vjesnik”, informujące o nasilonych aktach niszczenia pomników, oraz Serbskie Towarzystwo Kulturalne „Prosvjeta”, którego celem jest, aby poprzez swoje placówki w Chorwacji oraz w Bośni i Hercegowinie pielęgnować i rozwijać serbską tożsamość narodową ${ }^{16}$. Ostatnią podjętą przez nie inicjatywa jest otwarta w Zagrzebiu wystawa, ukazująca stan pomników na terenach chorwackich, co uzasadniać ma imperatyw ich utrzymania i konserwacji. Towarzystwo odgrywa też kluczową rolę w odnawianiu pomników zniszczonych po roku 1990. W ten sposób dzięki podejmowanym inicjatywom do roku 2012 z dużej liczby zdewastowanych i zburzonych pomników odnowiono około 400 upamiętnień walk antyfaszystowskich o różnej wartości artystycznej ${ }^{17}$. Wśród nich znalazł się pomnik ,Zamęczonym Więźniom" z obozu koncentracyjnego Jadovno, postawiony w 1988 roku, a zniszczony w 1991 roku. Odsłonięcie zrekonstruowanego monumentu nastąpiło w trakcie prywatnej, jak się zaznacza w relacjach prasowych, wizyty w Chorwacji prezydenta Serbii, Borisa Tadicia w 2011 roku.

Kolejnym odrestaurowanym pomnikiem jest rzeźba „Wezwanie do Powstania”, którą pierwotnie odsłonięto w 1947 roku w Bjelovarze ${ }^{18}$. Ten posąg, przedstawiający młodego człowieka z podniesionymi rękami i wyrazem twarzy wzywającym do walki, w byłej Jugosławii był uznawany za najlepsze odzwierciedlenie walk antyfaszystowskich i z tego powodu był multiplikowany w innych miejscach federacji (m.in. w Belgradzie na Dedinju). Zaraz po ogłoszeniu przez Chorwację niepodległości i walkach z armią jugosłowiańską w 1991 roku, pomnik został zaminowany i zniszczony. Zachowane elementy - dłoń i głowa postaci - znalazły się w muzeum Bjelovaru. Podjęta już po wojnie inicjatywa odnowienia pomnika zaowocowała jego rekonstrukcją i uroczystym odsłonięciem przez prezydenta Chorwacji Ivo Josipovicia w grudniu 2010 roku. Dziś pomnik jest miejscem spotkań grupy uznającej się za działaczy antyfaszystowskich Bjelovaru, która co roku w czerwcu,

\footnotetext{
${ }^{14}$ Rušenje antifašističkih spomenika u Hrvatskoj 1990-2000, red. Juraj Hrženjak, Savez antifašističkih boraca Hrvatske, Zagreb 2002.

${ }^{15}$ Najczęściej takim aktom podlega popiersie Ivo Loli Ribara (1916-1943), jednego z organizatorów i przywódców młodzieżowego i studenckiego ruchu rewolucyjnego w Jugosławii. Spomenik palim borcima NOB-a pod napadom istih fašista koji su napali bistu Ive Lole, „Antifašistički vjesnik” 18.10.2017. http://www.antifasisticki-vjesnik.org/hr/spomenici/3/Spomenik_palim_borcima_NOB_a_pod_napadom_istih_fasista_koji_su_napali_bistu_Ive_Lole/219/,(dostęp: 2.10.2019).

${ }^{16}$ A. Vladisavljevic, Refreshing Memories: Croatian Exhibition Recalls Lost Anti-Fascist Heritage, https:// balkaninsight.com/2019/10/02/refreshing-memories-croatian-exhibition-recalls-lost-anti-fascist-heritage/?utm source=Balkan+Transitional+Justice+Daily+Newsletter+-+NEW\&utm_campaign=81f911e9f0-BTJ_EN\&utm_ medium=email\&utm_term=0_a1d9e93e97-81f911e9f0-319753701, (dostęp: 2.10.2019).

${ }^{17}$ Informacje o autorach pomników stawianych w Chorwacji zaczerpnięto ze strony Popis antifašističkih spomenika u Hrvatskoj, https://hr.wikipedia.org/wiki/Dodatak:Popis_antifašističkih_spomenika_u_Hrvatskoj, (dostęp: 2.10.2019).

${ }^{18}$ Autorem pomnika Poziv na ustanak jest chorwacki rzeźbiarz pochodzenia serbskiego, Vojin Bakić.
} 
z okazji dnia walki z faszyzmem - pod pomnikiem uroczyście składa wieńce i kwiaty ${ }^{19}$. Innym rekonstruowanym w 2011 roku monumentem jest „Pomnik Powstania Narodu Chorwackiego" - zlokalizowany w okolicy miejscowość Srb, odsłonięty w 1951, a zniszczony w 1995 roku $^{20}$.

Poza odnawianiem niektórych zniszczonych u progu chorwackiej niepodległości pomników powstają nowe, upamiętniające krwawe i tragiczne wydarzenia z czasów wojny w latach 90. XX wieku. W ten sposób wypełnia się na nowo miejsca pamięci, zastępując te, które czciły pamięć poległych w walkach przeciwko armii niemieckiej. Za przykład posłużyć mogą losy pomnika „Wyzwolicieli Kninu” w północnej Dalmacji, przypominającego o bitwach, jakie toczyły się w okolicach tej miejscowości od 3 listopada do 3 grudnia 1944 roku $^{21}$. Odsłonięty w 1969 roku monument ze zbrojonego betonu o wysokości 25 metrów został zniszczony przez armię chorwacką na przełomie 1995/1996 roku i nigdy go nie odbudowano ${ }^{22}$. Upadek Jugosławii, późniejsza krwawa wojna, jaka wybuchła po proklamowaniu w 1991 roku niepodległości, a zakończona akcją „Burza” (Oluja), której centrum miało miejsce właśnie w Kninie, kiedy wojska chorwackie pokonały armię serbską, znalazła szereg upamiętnień w postaci pomników, tablic czy obelisków. Tu właśnie stanął przypominający o chorwackiej operacji zbrojnej pomnik, na którym obecnie Serbowie konsekwentnie nanoszą cyrylickie napisy ${ }^{23}$. Kwestia niszczenia, dewastacji, braku konserwacji pomników tego okresu do dziś pozostaje trwałym elementem sporów chorwacko-serbskich i prób rewizji historii wykorzystywanej do bieżącej walki politycznej ${ }^{24}$. W nowej rzeczywistości państwowej, poza oddziaływaniem stowarzyszeń antyfaszystowskich i swoistą kontrolą środowisk serbskich nad pomnikami i miejscami upamiętniania minionego czasu oraz zastępowania pomników okresu walk narodowowyzwoleńczych pomnikami wojny ostatniej dekady XX wieku, nastapiło zjawisko swoistego kultu pierwszego prezydenta Chorwacji, Franjo Tudjmana (1922-1999). „Ojciec narodu”, jak określają go często deskrypcje na posągach, doczekał się już ponad 80 odsłon w różnych miejscowościach, co potwierdzać ma zasługi tej postaci w uzyskaniu chorwackiej niezależności ${ }^{25}$.

\footnotetext{
${ }^{19}$ Dan antifašističke borbe obilježen u Bjelovaru: Antifašizam u Hrvatskoj je samo deklarativan, https://bjelovar.info/aktualno/dan-antifasisticke-borbe-obiljezen-u-bjelovaru-antifasizam-u-hrvatskoj-je-samo-deklarativan/, (dostęp: 12.09.2019).

${ }^{20}$ Liczący 15,5 m wysokości Spomenik ustanku naroda Hrvatske w Chorwacji występuje też pod nazwą „Pomnika Powstania Narodu Liki” (Spomenik ustanku naroda Like). Jego autorem jest chorwacki rzeźbiarz i poeta, Vanja Radauš.

${ }^{21}$ Spomenik oslobodiocima Knina przygotowali architekci Đorđe Romić i Grozdan Knežević oraz rzeźbiarz Mihail Kajfeš.

${ }^{22}$ Bogatego materiału dostarcza S. Horvatinčić, Spomenici iz razdoblja socijalizma u Hrvatskoj-prijedlog tipologije, Zadar 2017, https://repozitorij.unizd.hr/islandora/object/unizd\%3A1971, (dostęp: 13.09.2019).

${ }_{23}$ D. Ferić, Nakon spomenika srpskim stradalnicima, oštećen spomenik „Oluji” u središtu Knina, ,Šibenik news" 2013. http://mok.hr/vijesti/item/13190-nakon-spomenika-srpskim-stradalnicima-ostecen-spomenik-olujiu-sredistu-kni, (dostęp: 13.09.2019).

${ }^{24}$ E. Szperlik, op. cit., s 273.

${ }^{25}$ Największy z nich, odsłonięty w grudniu 2018 roku w Zagrzebiu, liczy 4,2 metra wysokości i jest dziełem znanego chorwackiego rzeźbiarza, Kuzme Kovačicia. Ostatni został postawiony pod koniec sprawowania rządów przez prezydent Kolindę Grabar-Kitarović w związku z obchodami kolejnej rocznicy zakończenia operacji „Oluja”. Zob. m.in.: Tudjman nasmijava narod, http://pogledaj.to/art/tudman-nasmijava-narod/, (dostęp: 20.02.2020).
} 
Zdecydowanie silniejsze antagonizmy dowodzące trwania wojny na pomnikowe symbole miały lub mają miejsce w Bośni i Hercegowinie. W przypadku tego państwa trudno mówić o przywracaniu pamięci o wydarzeniach, znaczących bitwach czy postaciach odzwierciedlanych w pomnikach tworzonych w epoce „braterstwa i jedności”. Na przykład żelbetonowy pomnik „Poległym Bohaterom”, często określany jako „Pięść Tito”, usytuowany w paśmie górskim i przełęczy Makljen - został odsłonięty przez Josipa Broza Titę w 35. rocznicę bitwy nad Neretwą w 1978 roku, ale nieznani sprawcy, już w okresie względnej stabilizacji, wysadzili go w powietrze w 2000 roku. Mimo że zachowała się tylko wewnętrzna konstrukcja jego belek nośnych, w roku 2010 Komisja Ochrony Zabytków $\mathrm{BiH}$ wpisała jego szczątki na listę narodowych pamiątek ${ }^{26}$. W ten sposób uchroniono go przed losem, jaki spotkał pomnik „Przenoszenie Rannego”, przedstawiający ranną postać podtrzymywaną przez dwóch towarzyszy. Powielana w całej Jugosławii rzeźba (m.in. Zagrzeb, Vukovar, Belgrad), wzniesiona w miejscowości Livno w 1952 roku, podobnie jak jego replika w Vukovarze, została wysadzona w 1992 roku przez HVO (Hrvatsko vijeće obrane - Chorwacka Rada Wojskowa) ${ }^{27}$. Zmienny los spotykał zwieńczony pięcioramienną gwiazdą obelisk postawiony w 1946 roku w miejscowości Bijelijna w Republice Serbskiej BiH, na miejscu obalonego przez Niemców w 1941 roku pomnika króla Piotra Karadziordziewicia. Na starym postumencie ustawiono w 1946 roku zwężającą się ku górze kolumnę z pięcioramienną gwiazdą, która po referendum niepodległościowym w 1991 roku została obalona, by ustąpić miejsca odtworzonej replice pomnika króla Piotra ${ }^{28}$.

Inicjatywy podejmowane w ramach poszczególnych kantonów realizowane są wbrew woli pozostałych członków wspólnoty państwowej, a dla oponentów są jedynie lansowaniem własnej pamięci i wartości w wieloetnicznym społeczeństwie. Wpisują się w nurt uzasadniania swego trwania $\mathrm{w}$ danej przestrzeni, podkreślania więzi etnicznych i swojego zanurzenia w tradycji. Pamięć historyczną w Bośni i Hercegowinie przywracają wszystkie zamieszkujące ją etnosy w lokalnych przedsięwzięciach odsłaniania pomników bohaterów wywodzących się z tych ziem lub uznanych za jej władców. I tak w 2012 roku w Tuzli powróciła pomnikowa pamięć o XIV-wiecznym pierwszym królu Bośni, Tvrtko I Kotromaniciu (1338-1391), uznawanym za najpotężniejszego z bośniackich władców średniowiecza $^{29}$, a w niewielkiej miejscowości Čapljina w południowej $\mathrm{BiH}$, w pobliżu granicy z Chorwacją, uwieczniono żyjącego w wieku X księcia Tomislava, uznawanego przez Chorwatów za ich pierwszego króla. Potwierdzaniem tożsamości narodów Bośni i Hercegowiny staje się manifestowanie przywiązania do własnej tradycji religijnej. Bośniaccy Serbowie podkreślają swoje związki z prawosławiem i Rosją, czego przykładem jest odsłonięta w kwietniu 2017 roku instalacja krzyża prawosławnego w Višegradzie ku czci

${ }^{26}$ Pomnik powstał według autorskiej koncepcji rzeźbiarza Boška Kućanskiego. Zob.: https://www.spomenikdatabase.org/bosko-kucanski, (dostęp: 9.10.2019).

${ }^{27}$ Autorem mulitiplikowanego w całej Jugosławii pomnika, zwanego w miejscowości Livno Palim borcima, jest chorwacki rzeźbiarz Antun Augustinčić.

${ }^{28}$ Т. Лазић, Споменик краљу Петру Карађорђевићу у Бијељини 1939-1993, „Зборник” nr 26, Спомен места - историја - сећања, red. Д. Радојичић, Етнографски институт САНУ, Београд 2009, s. $23-33$.

${ }^{29}$ Średniowieczny władca w czasie swego panowania uzależnił od siebie Księstwo Serbii, podbił Dalmację i odpierał liczne najazdy Turków osmańskich. Zob.: W. Felczak, T. Wasilewski, Historia Jugosławii, WrocławWarszawa-Kraków-Gdańsk-Łódź 1985, s. 120. Autorem jego pomnika jest młody rzeźbiarz Adis Lukač. Zob.: https://hamdocamo.wordpress.com/2017/01/09/adis-lukac-za-faktor-kako-mi-je-tvrtko-i-promijenio-zivot/, (dostęp: 10.03.2018). 
rosyjskich ochotników poległych w wojnie lat $90 .{ }^{30}$, podczas gdy Boszniacy - wspierani materialnie przez kraje islamskie - budują nowe meczety czy przywracają świetność sta$\mathrm{rym}^{31}$. Kwestia pamięci o ofiarach wojny - zakończonej wymuszonym porozumieniem w Dayton w 1995 roku - zdaje się potwierdzać jedynie, że każdy z etnosów kantonalnego państwa kultywuje pamięć tylko swojej historii, swoich ofiar i wydarzeń wojennych z własnego terytorium, co prowokuje kolejne nieporozumienia ${ }^{32}$.

Traktowanie pomnikowej przeszłości okresu NOB ma szczególny charakter w Serbii. Powstające w dobie titowskiej Jugosławii pomniki, poświęcone wydarzeniom II wojny światowej, mają tu niepodważalne i trwałe znaczenie. Dowodzą tego losy otwartego w 1953 roku kompleksu „Park Pamięci »Kragujewski Październik«” (Spomen-park Kragujevački oktobar), z dwunastoma pomnikami poświęconymi rozstrzelanym w październiku 1941 roku około trzem tysiącom mieszkańców miasta. W 1979 roku tenże park wpisany został na listę pomników o wyjątkowym znaczeniu i po dziś dzień stanowi miejsce pamięci poległych w czasie NOB. Odsłaniane tu w kolejnych latach pomniki stanowią kompleks, na który składają się dziś liczne instalacje przestrzenne serbskich rzeźbiarzy i architektów. Przypominając o poległych w okresie II wojny światowej, symbolizują ból, walkę i wolność. Najbardziej rozpoznawalny jest betonowy pomnik „Przerwany lot”, dedykowany rozstrzelanym uczniom i profesorom kragujewskiego gimnazjum. Już po rozpadzie Jugosławii odsłaniano tu kolejne rzeźby ku czci przedstawicieli różnych grup społecznych, którzy w czasie wojny stracili życie, choć właśnie wtedy pojawiły się także pomniki inspirowane mitologią starosłowiańską i stanowiące wizualizacje kobiecych bóstw ${ }^{33}$.

Pomniki upamiętniające wydarzenia i postacie z okresu II wojny światowej nadal zajmują przestrzeń miast i wsi, czy to w swych dotychczasowych lokalizacjach, czy też przenoszone są na godniejsze miejsca, jak na przykład pomnik „Zabitym Wojownikom NOB” w podbelgradzkiej gminie Surčin z 1953 roku, który z pierwotnego umiejscowienia

${ }^{30}$ D. Kovacevic, Bosnian Serbs Unveil Monument to Russian War Volunteers. Zob.: https://balkaninsight. com/2017/04/12/bosnian-serbs-unveil-monument-to-russian-war-volunteers-04-12-2017/, (dostęp: 20.09.2019).

${ }^{31}$ M. Zekić, Musilimanski odgovor izazovima Okcidenta. Islamizacija Zapada ili vesternizacija islamskog svijeta. S posebnim osvrtom na Bosnu i Hercegovinu i bosanskohercegovačke muslimane - Bošnjake, Poznań 2016, s. 411.

32 D. Brkanic, L. Grebo, Bosnia Spends $€ 2$ Million on 'Divisive' War Memorials, https://balkaninsight. com/2020/01/03/bosnia-spends-e2-million-on-divisive-war-memorials/, (dostęp: 3.01.2020).

${ }^{33}$ Zamysł stworzenia miejsca pamięci ofiar walk narodowowyzwoleńczych powstał według projektu Mihajlo Mitrovicia i Radivoja Tomicia. W kolejnych latach odsłaniano tam także inne pomniki, jak na przykład pomnik „Bólu i Buntu” (Spomenik bola i prkosa) rzeźbiarza Ante Gržeticia z 1959 roku, czy najbardziej znany, upamiętniający pomordowanych uczniów i ich nauczycieli pomnik „Przerwany Lot” (Prekinut let), rzeźbiarza Miodraga Živkovicia z 1963 roku. Do kompleksu pamięci włączono także pomnik „,Oporu i Wolności” (Spomenik otpora i slobode) rzeźbiarza Ante Gržeticia, odsłonięty w 1966 roku; pomnik „Kryształowego Kwiatu” (Spomenik Kristalni cvijet), „Czyścicieli Obuwia” (Spomenik čistačima obuće), poświęcony rozstrzelanym dzieciom romskim, zaprojektowany przez architekta Nebojšę Delję, a odsłonięty w 1968 roku oraz pomnik „Kamienny Śpiący” (Spomenik Kameni spavač), poświęcony mieszkańcom okolicznych wsi, zaprojektowany przez architektów Gradimira i Jelicę Bosnić, z 1970 roku. Kolejne odsłaniane były w następnych latach, np. pomnik „Stu za Jednego" (Sto za jednog) rzeźbiarza Nandora Glida z 1980 roku; stalowy monument, który miałby oddawać charakter narodu chorwackiego (Spomen - obilježje naroda Hrvatske), pomnik „Rozstrzelanym Serbom i Żydom” (Spomenik streljanim Srbima i Židovima) rzeźbiarza Vojina Bakicia i odsłonięty w 1991 roku już poza terenem parku pamięci czy betonowy pomnik „Przyjaźni” (Spomenik prijateljstva), wykonany według projektu architekta Antona Stojku, a odsłonięty w 1994 roku. 
przed budynkiem gminy został przeniesiony w 2012 roku na plac miejski ${ }^{34}$. Mnogość pomników z okresu titowskiego poświęconych wielkim wydarzeniom z okresu wojny partyzanckiej czy postaciom tego okresu, jak na przykład statua z 1963 roku Borisa Kidriča, postaci pomnikowej mazanej w Lublanie czerwoną farbą, w Parku Rzeźby Muzeum Sztuki Współczesnej (Park skulptura Muzeja savremene umetnosti) w Belgradzie nie wzbudza emocji, czy chęci dewastacji takich, jak barwione sprejami dokonania współczesnych twórców wystawiane w tym samym miejscu. Pamięć o tragicznej przeszłości II wojny światowej była kultywowana jeszcze tuż przed upadkiem Jugosławii, czego przykładem jest pomnik „Powieszonym na Terazije” z 1983 roku. Okragły rzeźbiony obelisk ma upamiętniać powieszenie przez gestapo na tejże ulicy 17 sierpnia 1941 pięciu mieszkańców miasta $^{35}$. Obok pomników kultywujących pamięć o ofiarach II wojny światowej w przestrzeni serbskiej istnieją stare i nowe artystyczne wizualizacje postaci związanych z wydarzeniami powstania 1804 roku. W lokalnym wymiarze, po rozpadzie Jugosławii przypomina się o pierwszym serbskim powstaniu antytureckim, a przykładem jest chociażby niepozorny pomnik „Ścięcie Książąt” z 2004 roku, usytuowany w miejscowości Valjevo i nawiązujący do tragicznej śmierci przywódców serbskiego zrywu ${ }^{36}$. Występują także pomniki honorujące rosyjsko-serbskie związki słowiańskie. Jednym z nich jest zainstalowany w Nowym Sadzie monument z 1992 roku poświęcony ofiarom ostatniej wojny dzieciom $^{37}$.

W serbskim kontekście utrzymywania pomników minionego okresu nie dziwi czarnogórska troska o ich zachowanie na swoim terytorium. Tu także, jak w całym federacyjnym państwie, odsłaniano pomniki upamiętniające wydarzenia II wojny. W wyniku referendum niepodległościowego Czarnogóra w roku 2006 stała się niezależnym państwem, wcześniej noszącym nazwę Federalna Republika Jugosławii (1992-2003), a od roku 2003 funkcjonowała jako dwupaństwo Serbia i Czarnogóra. I tutaj, podobnie jak w Serbii, samodzielność państwowa nie przyniosła aktów wandalizmu czy likwidowania wzniesionych wcześniej pomników. I tak monumentalny kompleks „Partyzantowi-Bojownikowi”, przy którym pochowano 97 bohaterów narodowych w Podgoricy, został uroczyście odsłonięty 12 lipca 1957 roku, przypominając o dniu, kiedy podczas kongresu berlińskiego w 1878 roku uznano Czarnogórę za dwudzieste siódme niepodległe państwo na świecie. Również tego dnia, w roku 1941 w Czarnogórze rozpoczęto pierwsze powszechne europejskie powstanie przeciwko państwom Osi. Przez lata ten kompleks pomnikowy stanowił centralne miejsce uroczystości państwowych i rocznic. Przy nim młodzi rekruci armii jugosłowiańskiej skła-

${ }^{34}$ Autorem pomnika (Spomenik palim borcima) jest Nebojša Mitrić. Zob.: https://sr.wikipedia.org/sr-ec/ Списак_споменика_НОБ_у_Србији, (dostęp: 25.09.2019).

${ }_{35}$ Āutorem rzeźby B. Kidrič oraz pomnika (Spomenik obešenim rodoljubima 1941) jest Nikola Janković. Zob.: 'Stećak' na Terazijama koji ste videli sto puta krije stravičan zločin i našu sramotu, https://www.dnevno. rs/istorija/beograd-u-proslosti/stecak-na-terazijama-koji-ste-videli-sto-puta-krije-stravican-zlocin-i-nasu-sramotu/, (dostęp: 20.09.2019).

${ }^{36}$ Autorem pomnika zasłużonego dla kultury serbskiej Matiji Proty Nenadovicia z roku 1984 oraz Seća knezova jest tworzący w USA, a wywodzący się z Valjeva rzeźbiarz Milomir Jevtić. Zob.: https://poznativaljevci. blogspot.com/2015/03/milomir-jevtic.html, (dostęp: 20.02.2020).

${ }^{37}$ Autorem tego pomnika jest wybitny rosyjski rzeźbiarz Wiaczesław Kłykow, którego „Krzyż Dziękczynny Narodów Słowiańskich" (Поклонный Крест славянских народов) propagowany jest w prawosławnym świecie. Pisałam o tym w artykule Współczesne wizualizacje dziedzictwa Cyryla i Metodego w przestrzeni słowiańskiej, „Zeszyty Cyrylo-Metodiańskie” 2019, nr 8, s. 145-146. 
dali przysięgę, a pionierzy ${ }^{38}$ otrzymywali czerwoną chustę. Tenże monument do dziś pełni państwowotwórczą rolę - nadal składa się pod nim wieńce i kwiaty, przedłużając symboliczne znaczenie hołdu poległym Czarnogórcom w walkach narodowowyzwoleńczych ${ }^{39}$. Swoistą formą pamięci o minionych czasach, czyniącą z Czarnogóry fenomen na tle innych pojugosłowiańskich państw, pozostaje jednak kontynuacja kultu Josipa Broza Tity. W Podgoricy w grudniu 2018 roku postawiono pomnik marszałka, pomnik, którego pierwotny wariant autorstwa chorwackiego rzeźbiarza Antuna Augustinčicia odsłonięto po raz pierwszy w 1948 roku w miejscu urodzenia przywódcy państwa w chorwackiej miejscowości Kumrovec. Ten właśnie kształt postaci Tity przez lata federacyjnej Jugosławii był powielany w wielu republikach Jugosławii (m.in. w Słowenii, BiH). W przypadku czarnogórskim jego wzniesienie uzasadniać ma ciągłość własnej tradycji państwowej, potwierdzając rolę Tity w procesie uzyskania narodowej niepodległości.

Pamięć o przeszłości, która miałaby udowadniać siłę państwa w proklamowanej w lutym 2008 roku Republice Kosowa, sprowadza się z kolei do pomnikowej rywalizacji, szczególnie w miejscach, gdzie zgodnie razem powinni funkcjonować Serbowie i Albańczycy. Trudna pamięć o wydarzeniach II wojny światowej zaowocowała w stolicy okręgu autonomicznego Kosowa i Metohii w 1961 roku pomnikiem „Braterstwa i Jedności”, który w roku 1970 został uzupełniony figurami partyzantów, zajmując wówczas miejsce zwane placem Braterstwa i Jedności ${ }^{40}$. Pomnik ten po wybuchu konfliktu zbrojnego, gdy Albańczycy wspierani byli siłami wojsk NATO, w swojej górnej partii został wysadzony w powietrze przez nieznanych sprawców jako symbol serbskiej dominacji. Gdy w roku 2000 zmieniono nazwę miejsca na plac Adema Jashariego (1955-1998), jednego z komendantów Armii Wyzwolenia Kosowa (UÇK - albańska zbrojna organizacja partyzancka działająca na terenie Kosowa), pomnik i jego pozostałości popadały w ruinę. Dopiero w roku 2018 władze miasta podjęły decyzję o jego odrestaurowaniu, ale nie podlega on żadnej specjalnej ochronie i figury z brązu pozostają pomazane farbami w kolorach różnych flag narodowych ${ }^{41}$.

Inną pamiątką minionych czasów jest zlokalizowany w enklawie serbskiej ${ }^{42}$, na wzgórzu opodal Kosowskiej Mitrowicy, odsłonięty w 1973 roku monumentalny pomnik poświęcony górnikom, bohaterom NOB, zwany też pomnikiem serbskich i albańskich partyzantów; oddaje on cześć uformowanym w tak zwaną grupę Rudarska četa górnikom kopalni Trepča. Żelbetonowy monument określany dziś przez miejscową ludność jako komunistyczny, chwały Miloševicia, albo ze względu na jego kształt, grillem, odzwierciedla apatię mieszkańców po obu stronach rzeki Ibar. Przez lata odbywały się pod nim ceremonie państwowe, zwykle 23 listopada, w dniu wyzwolenia Mitrowicy oraz 4 lipca, w dzień bojownika.

${ }^{38}$ Członkami organizacji, której celem było przygotowanie i wychowanie młodej kadry systemu komunistycznej Jugosławii, stawali się uczniowie klas pierwszych szkoły podstawowej. Podczas święta państwowego, Dnia Republiki, obchodzonego w całej Jugosławii 29 listopada, dzieci otrzymywały wszystkie atrybuty pioniera - czerwoną chustę i czapkę z pięcioramienną gwiazdą. Zob.: К. Камбарески, Детски организации, [w:] Македонска енциклопедија, red. Б. Ристовски, t. 1, s. 459.

${ }^{39}$ Pomnik Partizanu-borcu został zaprojektowany przez architekta Vojslava Džokicia i rzerźbiarza Drago Djurovicia.

${ }^{40}$ Autorem pomnika Palim borcima jest Miodrag Živković.

${ }^{41}$ Autorem pomnika, którego obecna nazwa katalogowa to „Pomnik Rewolucji w Prisztinie”, jest Miodrag Živković. Zob. więcej: https://www.spomenikdatabase.org/pristina, (dostęp: 2.10.2019).

${ }^{42}$ P. Marcinkowska, Kosowo jako suwerenne państwo. Teoria i praktyka, Warszawa 2016. 
Dzisiaj w następstwie konfliktu etnicznego stracił na znaczeniu - zaniedbywany, podlegający aktom wandalizmu stał się dla jednych punktem widokowym panoramy miasta, a dla drugich od roku 2015 przestrzenią, na której można uprawiać jogę, świętując Międzynarodowy Dzień Jogi ${ }^{43}$.

Obie grupy etniczne poprzez obecnie stawiane pomniki zaznaczają swoje trwanie w Kosowie. W Mitrowicy Serbowie przywołują pamięć księcia Lazara, bohatera bitwy na Kosowym Polu. Odsłonięty w rocznicę kosowskiej bitwy, 28 czerwca 2016 roku pomnik, z ręką postaci skierowaną w kierunku miejsca bitwy, ma przypominać o serbskiej przeszłości ziem, na których powstało nowe, obce państwo. Służy to podtrzymywaniu wizji narodu serbskiego jako niezłomnego i niepokonanego ${ }^{44}$. Nie jest to jednak działanie jednokierunkowe. Także Albańczycy sięgają do swej przeszłości, dowodząc własnego miejsca w Kosowie oraz w Kosowskiej Mitrowicy. Oni także przywołują pamięć swoich przodków. Pomnikowa rywalizacja i tu urasta do walki na symbole, uzasadniając prawo do zajmowanego terytorium. Pierwszoplanowe miejsce przypada pomnikowemu upamiętnieniu Skanderbega (Prisztina), a kolejne, już nowożytne postacie wchodzą do panteonu albańskich bohaterów narodowych. W 100. rocznicę ogłoszenia niepodległości Albanii oraz z okazji Dnia Flagi 28 listopada 2012 roku odsłonięto w Mitrowicy pomnik Isy Boletiniego (18641916), dowódcy powstań antyosmańskich. Hołd oddaje się także politykowi i działaczowi narodowemu Hasanowi Prishtinie (właśc. Hasan Bej Vuçiterna, 1873-1933). Jak twierdzą badacze, w porównaniu z innymi posocjalistycznymi państwami bałkańskimi proces tranzycji „narzuconej” z zewnątrz trwa tam wyjątkowo długo i cofnął prowincje w rozwoju w każdym obszarze społecznym, politycznym i gospodarczym. Trudno więc będzie przeprowadzić tam trwałe zmiany systemowe, dopóki spór o terytorium Kosowa i Metochii nie zostanie rozwiązany przez samych Serbów i Albańczyków, bez udziału mocarstw zachodnich i Rosji, które kierują się na Bałkanach własnym interesem ${ }^{45}$.

Także Macedonia, dziś funkcjonująca pod oficjalną nazwą Republika Macedonii Północnej, jako część składowa federacji jugosłowiańskiej obdarzona została licznymi pomnikami wojny narodowowyzwoleńczej lat 1941-1945. Choć wiele z nich przetrwało, to okazało się, że po zmianach systemowych nie były niszczone planowo - kwestię ich dalszego istnienia regulował upływ czasu - zaniedbane pomniki zaczęły popadać w ruinę. Tak działo się z nietypowym, jak na warunki minionej doby pod względem wykonania i projektu pomnikiem Wolności, usytuowanym na wzgórzu Lokubija w Kočani. Budowa cementowych ścian, pokrytych mozaikami w latach 1975-1977, zakończyła się odsłonięciem monumentu w roku 1981, podczas uroczystych obchodów Dnia Republiki (Dan Republike). Mozaiki zajmujące $335 \mathrm{~m}^{2}$ powierzchni obrazowały walki narodu macedońskiego o wolność od czasów powstania ilindeńskiego w 1903 roku po wyzwolenie. Pomnik pełnił też funkcje użytkowe, gdyż w składającym się nań amfiteatrze organizowano uro-

\footnotetext{
${ }^{43}$ Pomnik Rudarima junacima iz narodnooslobodilake borbe - zwany też jako Spomenik srpskim i albańskim partizanima - powstał on według projektu Bogdana Bogdanovicia https://www.spomenikdatabase.org/mitrovica, (dostęp: 2.10.2019).

${ }^{44}$ Autorem pomnika jest Miroljub Stamenković. Zob. więcej: https://ozoutback.com.au/Kosovo/mitrovica/ slides/06_20181010008.html, (dostęp: 2.10.2019).

${ }_{5}$ J. Wiśniewski, Próby rozwiazania kryzysu kosowskiego przez mocarstwa zachodnie i Rosję w okresie tranzycji Republiki Serbii w latach 1998-1999, [w:] 25 lat transformacji w krajach Europy Środkowej $i$ Wschodniej, red. M. Barański, J. Wiśniewski, Katowice 2014, s. 155-166.
} 
czyste akademie i zgromadzenia, a jako miejsce pamięci znalazł się w rejestrach chronionych przez państwo pamiątek kultury. Po usamodzielnieniu się Macedonii jako niezależnego bytu w 1991 roku pozostawał jednak bez dozoru i był dewastowany przez miejscową ludność, która do roku 2004 zniszczyła część mozaik, pokrywając je graffiti. Władze miasta w 2018 roku wystapiły do banku światowego o fundusze, które mogłyby sam pomnik i jego otoczenie przywrócić do użytku, licząc na to, że w odrestaurowaniu i przywróceniu jego funkcji pomoże organizowanie tam imprez masowych ${ }^{46}$.

Innym spektakularnym upamiętnieniem ofiar II wojny światowej jest memoriał „Kostnica" (Костурница), odsłonięty w Velesie w 1979 roku. Ten także stał się przedmiotem aktów wandalizmu. Pokrywany graffiti monument, skrywający szczątki poległych, w nowych czasach popadał stopniowo w coraz większą ruinę, dokumentując brak zainteresowania władz przeszłością tego okresu ${ }^{47}$. Przez lata podobnym aktom niszczenia i obojętności rządzących podlegał pomnik przedstawiający pod postacią kobiety „Zwycięstwo”, odsłonięty w 1961 roku w Tetowie. Postument, na którym postawiono postać odlaną z brązu, odrestaurowano dopiero w 2018 roku staraniem miejscowego muzeum ${ }^{48}$. Okres trwania suwerennej Macedonii, kiedy niszczały pomniki upamiętniające NOB, przyniósł też zjawisko, które nie zaistniało w pojugosłowiańskich państwach - ,zalew pomników” (Denkmalsflut $)^{49}$. W wymiarze lokalnym i państwowym pamięć o wielkich postaciach z dziejów ziem macedońskich zaowocowała wielkim projektem „Skopje 2014”, włączającym do historii własnego państwa bohaterów antycznego państwa macedońskiego, postacie ze średniowiecznej historii tych ziem, jak i postacie, które w okresie trwania Socjalistycznej Republiki Macedonii były całkowicie przemilczane ${ }^{50}$.

Przedstawiony materiał dokumentuje sposoby traktowania pomnikowej pamięci o przeszłości w państwach, które ukonstytuowały się po rozpadzie Jugosławii. Wskazane przykłady, które jednak nie wyczerpują tematu, ukazują, że proces transformacji w sferze symbolicznej nie tworzy jednorodnego obrazu we wszystkich krajach. Oscyluje on od zjawiska niszczenia pomników minionego okresu w Słowenii, Chorwacji oraz Bośni i Hercegowinie, ale i kultywowania w różnym natężeniu wydarzeń tragicznej wojny ostatniej dekady XX wieku. Wyłamująca się z takiego opisu Serbia chroni pomniki doby jugosło-

${ }^{46}$ Споменик на слободата powstał według projektu Gligora Cemerskiego i Radovana Ragenovika. Zob.: https://a1 on.mk/culture/kulturni-nastani-kje-zazhivee-zapushteniot-spomenik-na-slobodata-vo-kochani/ (dostęp: 3.10.2019).

${ }^{47}$ Autorem budowanego przez 3 lata memoriału Споменик Костурница o rozmiarach 10 m wysokości i 15 m szerokości jest serbski artysta Ljubomir Denković. Zob.: https://kosturnica-veles.blogspot.com/; https:// www.spomenikdatabase.org/veles (dostęp: 3.10.2019).

48 „ППбеда” / Борка Аврамова. Zob.: https://marh.mk/pobeda-borka-avramova/ (dostęp: 3.10.2019).

${ }^{49} \mathrm{O}$ fenomenie wzmożonego stawiania pomników pisał Hans A. Pohlsander, odnosząc go do sytuacji na ziemiach niemieckich w XIX wieku, kiedy sfera symboliczna odegrała istotną rolę w procesie jednoczenia Niemiec. Zob.: H.A. Pohlsander, National Monuments and Nationalism in 19th Century Germany, Oxford, Bern, Berlin, Bruxelles, Frankfurt am Main, New York, Wien 2008.

${ }^{50}$ Pomniki Aleksandra Wielkiego (Воин на коњ), Justyniana III, cara Symeona i in. stawiane były w ramach budzącego kontrowersje rządowego projektu „Skopje 2014”, który miał przywracać klasyczny wygląd miasta sprzed trzęsienia ziemi w 1963 roku. O zjawisku pisali m.in.: M. Kawka, O pomnikach i statuach w macedońskim dyskursie parlamentarnym, [w:] Macedoński dyskurs niepodległościowy, red. I. Stawowy-Kawka, M. Kawka, Kraków 2011, s. 91-98; L. Moroz-Grzelak, Macedońska pamięć historyczna. Imaginarium pomnikowe, [w:] Bałkany Zachodnie między przeszłościq a przyszłościq, red. P. Chmielewski, S.L. Szczesio, Łódź 2012, s. 381-395; Д. Поповска, Споменикот, меморијата и идентитетот, Скопје 2015. 
wiańskiej, przywołując jednocześnie pamięć o serbskim zrywie wolnościowym w powstaniu antytureckim 1804 roku. Ochrona pomników okresu NOB w Czarnogórze dowodzi nie tylko związków z federacyjną Jugosławią, ale także odzwierciedla swoistą jugonostalgię. Z kolei zachowane w różnym stanie pomniki tego okresu na terytorium Macedonii ustapiły „zalewowi pomników” odnoszących się do antycznej i średniowiecznej historii tych ziem. Przemiany w sferze pomnikowej we wszystkich krajach dowodzą jednak chęci uzasadniania ideologicznego istnienia samodzielnych bytów państwowych osadzonych w rodzimej tradycji potwierdzającej własną suwerenność.

\section{Bibliografia}

Monografie:

Assmann A., Między pamięciq a historiq. Antologia, red. M. Saryusz-Wolska, Warszawa 2013.

Felczak W., Wasilewski T., Historia Jugosławii, Wrocław-Warszawa-Kraków-Gdańsk-Łódź 1985.

Pohlsander H.A., National Monuments and Nationalism in 19th Century Germany, Oxford, Bern, Berlin, Bruxelles, Frankfurt am Main, New York, Wien 2008.

Поповска Д., Споменикот, меморијата и идентитетот, Скопје 2015.

Rušenje antifašističkih spomenika u Hrvatskoj 1990-2000, red. J. Hrženjak, Zagreb 2002.

Szperlik E., Chorwacka (nie)pamięć o Jugostawii. Przemilczenia, pominięcia i odpamiętanie w prozie chorwackiej po roku 1991, Poznań 2019.

Waldenberg M., Rozbicie Jugosławii: jugostowiańskie lustro międzynarodowej polityki, t. 1-2, Warszawa 2005.

Zacharias M., Komunizm, federacja, nacjonalizmy. System władzy w Jugosławii 1943-1991. Powstanie, przeksztatcenia, rozkład, Warszawa 2004.

Zekić M., Musilimanski odgovor izazovima Okcidenta. Islamizacija Zapada ili vesternizacija islamskog svijeta. S posebnim osvrtom na Bosnu i Hercegovinu i bosanskohercegovačke muslimane - Bošnjake, Poznań 2016, s. 411.

Artykuły:

Kawka M., O pomnikach i statuach w macedońskim dyskursie parlamentarnym, [w:] Macedoński dyskurs niepodległościowy, red. I. Stawowy-Kawka, M. Kawka, Kraków 2011, s. 91-98.

Камбарески К., Детски организации, [w:] Македонска енииклопедија, red. Б. Ристовски, t. 1. Скопје 2009, s. 458-459.

Лазић Т., Споменик краљу Петру Карађорђевићу у Бијељини 1939-1993, „Зборник”, nr 26, Спомен места - историја - сећањ , red. Д. Радојичић, Етнографски институт САНУ, Београд 2009, s. 23-33.

Łopaciński H., Pomniki, [w:] Z. Gloger, Encyklopedia staropolska ilustrowana, t. 4, reprint, wstęp J. Krzyżanowski, Wiedza Powszechna, Warszawa 1978, s. 72-94

Marcinkowska P., Kosowo jako suwerenne państwo. Teoria i praktyka, Warszawa 2016.

Moroz-Grzelak L., Emblematyczne formy manifestowania wartości w świecie postjugosłowiańskim. Patriotyzm, [w:] Konstrukcje i destrukcje tożsamości. Wartości w świecie słowiańskim, red. E. Golachowska, D. Pazio-Wlazłowska, Warszawa 2015, s. 355-368.

Moroz-Grzelak L., Macedońska pamięć historyczna. Imaginarium pomnikowe, [w:] Bałkany Zachodnie między przeszłościq a przyszłościq, red. P. Chmielewski, S.L. Szczesio, Łódź 2012, s. 381-395.

Moroz-Grzelak, L., Współczesne wizualizacje dziedzictwa Cyryla i Metodego w przestrzeni słowiańskiej, „Zeszyty Cyrylo-Metodiańskie”, 2019, nr 8, s. 140-154. 
Wiśniewski J., Próby rozwiqzania kryzysu kosowskiego przez mocarstwa zachodnie i Rosję w okresie tranzycji Republiki Serbii w latach 1998-1999, [w:] 25 lat transformacji w krajach Europy Środkowej i Wschodniej, red. M. Barański, J. Wiśniewski, Katowice 2014, s. 155-166.

Źródła internetowe:

Brkanic D., Grebo L., Bosnia Spends $€ 2$ Million on 'Divisive'War Memorials, https://balkaninsight. com/2020/01/03/bosnia-spends-e2-million-on-divisive-war-memorials/, (dostęp: 3.01.2020).

Dan antifašističke borbe obilježen u Bjelovaru: Antifašizam u Hrvatskoj je samo deklarativan, https://bjelovar.info/aktualno/dan-antifasisticke-borbe-obiljezen-u-bjelovaru-antifasizam-uhrvatskoj-je-samo-deklarativan/, (dostęp: 12.09.2019).

Ferić D., Nakon spomenika srpskim stradalnicima, oštećen spomenik „Oluji” u središtu Knina, „Šibenik news” 2013. http://mok.hr/vijesti/item/13190-nakon-spomenika-srpskim-stradalnicimaostecen-spomenik-oluji-u-sredistu-kni, (dostęp: 13.09.2019).

Horvatinčić S., Spomenici iz razdoblja socijalizma u Hrvatskoj - prijedlog tipologije, Zadar 2017, https://repozitorij.unizd.hr/islandora/object/unizd\%3A1971, (dostęp: 13.09.2019).

Hribar P., Ne spomenik vsem žrtvam vojn, pač pa Slovencu vojaku. „Casovnik”. https://www.casnik. si/spomenik-posvecen-vsem-zrtvam-vojn/, (dostęp: 29.09.2019).

Kovacevic D., Bosnian Serbs Unveil Monument to Russian War Volunteers, https://balkaninsight. com/2017/04/12/bosnian-serbs-unveil-monument-to-russian-war-volunteers-04-12-2017/, (dostęp: 20.09.2019).

Lešničar T., Kako in komu postavljamo spomenike, „Delo” 2017, https://www.delo.si/sobotna/kakoin-komu-postavljamo-spomenike.html, (dostęp: 10.09.2019).

Lisjak M., Če je to vredno 1,2 milijona, je 2. tir še zelo poceni, https://www.rtvslo.si/mmcdebata/ mmcdebata-ce-je-to-vredno-1-2-milijona-je-2-tir-se-zelo-poceni/427744, (dostęp: 29.09. 2019).

Popis antifašističkih spomenika u Hrvatskoj, https://hr.wikipedia.org/wiki/Dodatak:Popis_antifašističkih_spomenika_u_Hrvatskoj, (dostęp: 2.10.2019).

Simboli polpretekle zgodovine, http://spomeniki.blogspot.com/search/label/AVNOJ, (dostęp: 9.09.2019).

Spomenik palim borcima NOB-a pod napadom istih fašista koji su napali bistu Ive Lole, „Antifašistički vjesnik" 18.10.2017. http://www.antifasisticki-vjesnik.org/hr/spomenici/3/Spomenik_palim_borcima_NOB_a_pod_napadom_istih_fasista_koji_su_napali_bistu_Ive_Lole/219/, (dostęp: $2.10 . \overline{2019)}$.

'Stećak' na Terazijama koji ste videli sto puta krije stravičan zločin i našu sramotu, https://www. dnevno.rs/istorija/beograd-u-proslosti/stecak-na-terazijama-koji-ste-videli-sto-puta-krije-stravican-zlocin-i-nasu-sramotu/, (dostęp: 20.09.2019).

Tudjman nasmijava narod, http://pogledaj.to/art/tudman-nasmijava-narod/, (dostęp: 20.02.2020).

V Ljubljani oskrunili več spomenikov, https://www.rtvslo.si/crna-kronika/v-ljubljani-oskrunili-vecspomenikov/493550; z 3.07.2019, (dostęp: 29.09.2019).

Vladisavljevic A., Refreshing Memories: Croatian Exhibition Recalls Lost Anti-Fascist Heritage, https://balkaninsight.com/2019/10/02/refreshing-memories-croatian-exhibition-recalls-lostanti-fascist-heritage/?utm_source=Balkan+Transitional+Justice+Daily+Newsletter++ NEW\&utm_campaign=81f911e9f0-BTJ_EN\&utm_med ium=email\&utm_term=0_a1d9e93e9781f911e9f0-319753701, (dostęp: 2.10.2019).

Vučetić Škrbić A., Tadić u Jadovnom: Rušenjem spomenika prikrivao se zločin, „Slobodna Dalmacija”, 26.06.2011. https://www.slobodnadalmacija.hr/novosti/hrvatska/clanak/id/136147/ cpg/2, (dostęp: 12.09.2019).

„Победа” / Борка Аврамова. Zob.: https://marh.mk/pobeda-borka-avramova/, (dostęp: 3.10. 2019). 
http://spomeniki.blogspot.com/search/label/AVNOJ, (dostęp: 9.09.2019).

https://www.spomenikdatabase.org/bosko-kucanski, (dostęp: 9.10.2019).

https://hamdocamo.wordpress.com/2017/01/09/adis-lukac-za-faktor-kako-mi-je-tvrtko-i-promijeniozivot/, (dostęp: 10.03.2018).

https://sr.wikipedia.org/sr-ec/Списак_споменика_НОБ_у_Србији, (dostęp: 25.09.2019).

https://poznativaljevci.blogspot.com/2015/03/milomir-jevtic.html, (dostęp: 20.02.2020).

https://www.spomenikdatabase.org/pristina, (dostęp: 2.10.2019).

https://www.spomenikdatabase.org/mitrovica, (dostęp: 2.10.2019).

https://ozoutback.com.au/Kosovo/mitrovica/slides/06_20181010008.html, (dostęp: 2.10.2019).

https://a1 on.mk/culture/kulturni-nastani-kje-zazhivee-zapushteniot-spomenik-na-slobodata-vo-ko-

chani/, (dostęp: 3.10.2019).

https://kosturnica-veles.blogspot.com/, (dostęp:3.10.2019).

https://www.spomenikdatabase.org/veles, (dostęp:3.10.2019).

Lilla Moroz-Grzelak, dr hab., profesor w Instytucie Slawistyki PAN. Autorka artykułów, spośród których wyróżnia tekst Polska wizja batkańskiej przestrzeni terytorialnej w kontekście pojęcia kocioł bałkański (Slavia Meridionalis, 2007/7) oraz monografii Aleksander Wielki a macedońska idea narodowa. Stowiańskie losy postaci antycznej (Slawistyczny Ośrodek Wydawniczy, Warszawa 2004) i Bracia Stowianie. Wizje wspólnoty a rzeczywistość (Slawistyczny Ośrodek Wydawniczy, Warszawa 2011). Na podstawie południowosłowiańskich i polskich materiałów źródłowych bada wyrosłe w tej przestrzeni mity ideologiczne ukazujące m.in. zderzenie światów Slavia Latina i Slavia Orthodoxa.

ORCID-0000-0001-5176-2804

lilla.moroz-grzelak@ispan.waw.pl 